\title{
Studies on Efficiency of Medicinal Plants against Bacteria Isolated from Urinary Tract Infection
}

\author{
R. Senthil Kumar* and V. Parameshwari \\ Department of Microbiology, PG Extension Centre, Bharathidasan University, \\ Perambalur, Tamil Nadu, India \\ *Corresponding author
}

\begin{tabular}{|c|c|}
\hline & A B S T R A C T \\
\hline $\begin{array}{l}\text { K e y w o r d s } \\
\text { Antibacterial } \\
\text { activity, Urinary } \\
\text { Tract Infection, } \\
\text { Medicinal plants. }\end{array}$ & \multirow{3}{*}{$\begin{array}{l}\text { The study was to investigate the antibacterial activity of some medicinal plants } \\
\text { against Urinary Tract Infection (UTI) causing pathogens. Bacteria isolated from } \\
\text { the UTI infected patients were characterized by microscopic, staining and } \\
\text { morphological and biochemical evaluations. Crude extracts of the selected } \\
\text { medicinal plants prepared were checking their antibacterial activity against the } \\
\text { bacteria isolated from UTI infected patients. The zone of inhibitions was } \\
\text { compared with the zone of inhibition of standard antibiotics. The present study } \\
\text { revealed that Allium sativum had remarkable antibacterial activity compared to } \\
\text { other plant extracts than the others studied Tridax procumbens and latex of } \\
\text { Calotropis gigantea had lowest antibacterial activity. }\end{array}$} \\
\hline Article Info & \\
\hline $\begin{array}{l}\text { Accepted: } \\
\text { 18 December } 2016 \\
\text { Available Online: } \\
\text { 10 January } 2017\end{array}$ & \\
\hline
\end{tabular}

\section{Introduction}

Urinary tract infection (UTI) is a bacterial infection that affects any part of the urinary tract. UTI is an important cause of morbidity and mortality in Indian subjects affecting all age groups across the life span. Urinary tract infection can be defined by the presence of significant quality of bacteria in the urine along with signs and symptoms of infection (Zelikovic et al., 1992).

Urinary tract infections are serious health problem affecting millions of people each year (Elder, 2004). Worldwide, about 150 million people are diagnosed with UTI each year.
It is estimated that about $35 \%$ of healthy women suffer with UTI infection at some stage in their life. About 5\% of women each year suffer with the problem of painful urination (dysuria) and frequency. The incidence of UTI is greater in women than men, which may be either due to anatomical predisposition or urothelial mucosal adherence to the muco-polysaccharide lining or other host factors (Schaffer et al., 2001).

UTIs in men are not as common as in women but can be serious when they occur. More than $95 \%$ of UTI are caused by single bacterial species $E$. coli which is the most 
frequently infecting organisms (Kebira et al., 2009).

E. coli is one of the most common bacteria capable of causing infection in humans, particularly urinary tract infections (Iroha $e t$ al., 2009). Urinary tract infections are usually caused by the intestinal bacteria $E$. coli. These are necessary for digestion, but if they find their way into bladder and grow there and cause a UTI (Mayo Clinic Staff, 2012).

Several potent antibiotics are available for the treatment of UTI, but increasing drug resistance among bacteria has made therapy of UTI difficult. Bacteria have the genetic ability to transmit and acquire resistance to drugs (Akenga et al., 2005).

The antibacterial activities of some medicinal plants used against UTI causing pathogens were studied in recent time. Bacteria isolated from the UTI infected patients were characterized by microscopic, staining, morphological and biochemical evaluations. The ethanol extracts of some selected medicinal plants were used to assess the antibacterial activity against the UTI bacterial pathogens.

\section{Materials and Methods}

\section{Sample collection}

To isolate and identify the bacteria from urinary tract infection, samples were collected from 50 patients affected with UTI at Government Hospital, Perambalur, and Tamilnadu. Among the 50 patients 20 male, 30 female candidates age group between 25 40 years old. The infected midstream urine samples were collected in sterile screw cap container at 7 am to 11 am, February 2016. After sample collection the samples were brought to the laboratory in an ice cold condition.

\section{Isolation and identification of bacterial pathogen}

For isolation of UTI bacterial strains, loop full of urine samples were streaked on Mac Conkey agar, Blood agar and Nutrient agar plates (Hi Media, India) and incubated at 37 $\pm 2^{\circ} \mathrm{C}$ for $24 \mathrm{hrs}$. After incubation, colonies were characterized on the basis of morphological, cultural physiological and biochemical characteristics (Mac Faddin, 2000). A presumptive identification was performed by Gram staining, catalase production, oxidase activity, hydrogen sulfide production, Indole test, VogesProskauer test. The bacterial isolates were identified with the help of Bergey's Manual of Systematic Bacteriology (Kreig and Holt, 1984).

\section{Medicinal plants selected}

A total of four medicinal plants Viz. Zingiber officinale (rhizome), Allium sativum (bulb), Tridax procumbens (whole plant) and Calotropis gigantea (latex) were collected from Perambalur Dt. Tamilnadu during March 2016.

\section{Extraction of plant material}

Healthy plants were thoroughly washed with distilled water to get crude extract. The crude fresh extract was obtained by using mortar and pestle.

\section{Antibacterial activity of test plant extracts}

Susceptibility of UTI isolates to the plant extracts was determined by the disc diffusion assay (Shokeen et al., 2009). Petri plates containing Muller Hinton Agar medium were seeded with $24 \mathrm{hrs,} \mathrm{old} \mathrm{culture}$ of bacterial isolates. The sterile Whatman filter paper discs $(6 \mathrm{~mm}$ in diameter $)$ 
impregnated with test plants extract $(20 \mu \mathrm{l})$ were placed on the surface of the culture plates and incubated at $37^{\circ} \mathrm{C}$ for $24 \mathrm{hrs}$ and zone of inhibition was measured in diameter (mm).

\section{Disc diffusion method}

The isolated bacterial species were tested for the antibacterial susceptibility test against standard antibiotics. The test was done by disc diffusion method as recommended by CLSI M45 - A2 guidelines on Muller Hinton agar (CLSI, 2015). The commercially available standard antibiotics viz amoxycillin, ciproflaxacin, erythromycin, streptomycin and tetracyclin were used.

\section{Results and Discussion}

A total of 50 urine samples were analysed for isolation of predominant bacterial pathogens. Out of which most of the samples showed prominent bacterial count.
Few of the samples showed very low bacterial count. The demographic characterization of the patients showed that, the majority of them (54\%) living in urban area. Significant proportions were females $(60 \%)$, in the age group of 25 to 40 years, 38 married $(76 \%)$ and 26 were either illiterate or capable of read and write or up to $8^{\text {th }}$ grade $(52 \%)$ (Table 1$)$. Six bacteria were isolated from 50 urine samples. The isolates were characterized and identified by studying different properties as mentioned in materials and methods. The identification characteristics were confirmed with standard manual (Krieg and Holt, 1984). The biochemical characteristics revealed that, these isolates belonging to 6 genera (Table 2). Of these Escherichia coli, Klebsiella pneumonia, Pseudomonas aeuroginosa, Staphylococcus aureus, Streptococcus pyogens and Serratia marcencis were identified. Similarly, this same pattern of bacteria was reported by Kunin, (1997) and Tabassum et al., (2013).

Table.1 Characteristics of urine culture positive patients

\begin{tabular}{|c|c|c|}
\hline Variables & Number & Percentage \\
\hline \multicolumn{3}{|l|}{ Location } \\
\hline Urban & 27 & 54 \\
\hline Rural & 23 & 46 \\
\hline \multicolumn{3}{|c|}{$25-40$} \\
\hline \multicolumn{3}{|l|}{ Sex } \\
\hline Male & 20 & 40 \\
\hline Female & 30 & 60 \\
\hline \multicolumn{3}{|l|}{ Martial status } \\
\hline Single & 12 & 24 \\
\hline Married & 38 & 76 \\
\hline \multicolumn{3}{|l|}{ Education level } \\
\hline Illiterate & 6 & 12 \\
\hline Write and read only & 8 & 16 \\
\hline Up to 8 grade & 12 & 24 \\
\hline SSLC & 5 & 10 \\
\hline HSC & 11 & 22 \\
\hline University level & 8 & 16 \\
\hline
\end{tabular}


Table.2 Biochemical characteristic testing of bacterial isolates from urine sample

\begin{tabular}{|l|c|c|c|c|c|c|}
\hline Parameters & Bacteria 1 & Bacteria 2 & Bacteria 3 & Bacteria 4 & Bacteria 5 & Bacteria 6 \\
\hline Indole & + & - & - & - & - & - \\
\hline MR & + & - & - & + & - & + \\
\hline VP & - & + & - & + & - & + \\
\hline Citrate & - & + & + & - & - & + \\
\hline TSI & - & + & + & + & - & - \\
\hline $\mathrm{H}_{2} \mathrm{~S}$ & - & + & - & - & - & - \\
\hline Urease & - & + & - & - & - & + \\
\hline Catalase & - & - & + & + & - & + \\
\hline Oxidase & - & - & + & + & + & - \\
\hline
\end{tabular}

Table.3 Bacteria isolated from the urine sample of UTI patients

\begin{tabular}{|l|l|}
\hline S.No & Name of the organism \\
\hline 1. & Escherichia coli \\
\hline 2. & Klebsiella pneumonia \\
\hline 3. & Pseudomonas aeuroginosa \\
\hline 4. & Staphylococcus aureus \\
\hline 5 & Streptococcus pyogens \\
\hline 6 & Serratia marcensis \\
\hline
\end{tabular}

Table.4 The effect of antibacterial susceptibility testing of isolated UTI bacterial pathogens

\begin{tabular}{|l|c|c|c|c|c|c|}
\hline \multirow{2}{*}{$\begin{array}{l}\text { Standard } \\
\text { Antibiotics }\end{array}$} & \multicolumn{7}{|c|}{ Name of the bacterial isolates } \\
\cline { 2 - 7 } & $\boldsymbol{E}$. coli & $\boldsymbol{K}$. pneumonia & $\boldsymbol{P}$. aeuroginosa & S. aureus & S. pyogens & S. marcencis \\
\hline Streptomycin & MS & R & MS & R & MS & S \\
\hline Amoxycillin & R & R & S & R & S & S \\
\hline Tetracyclin & R & MS & S & R & MS & S \\
\hline Erythromycin & S & S & MS & R & MS & S \\
\hline Ciproflaxacin & S & S & S & S & S & S \\
\hline
\end{tabular}

Note: S- Sensitive, MS- Moderate Sensitive, R- Resistant

Table.5 The effect of antibacterial activity of crude plant extracts on UTI bacterial isolates

\begin{tabular}{|l|c|c|c|c|c|c|}
\hline \multirow{2}{*}{$\begin{array}{l}\text { Crude Plant } \\
\text { Extracts }\end{array}$} & \multicolumn{7}{|c|}{ Zone of inhibition in diameter (mm) } \\
\cline { 2 - 7 } & E. coli & K. pneumonia & P. aeuroginosa & S. aureus & S. pyogens & S. marcencis \\
\hline Z. officinale & $10.33 \pm 0.57$ & $7.67 \pm 0.60$ & $6.57 \pm 0.33$ & $7.30 \pm 0.57$ & $8.70 \pm 0.60$ & $7.30 \pm 0.57$ \\
\hline A. sativum & $22.33 \pm 0.60$ & $20.10 \pm 0.33$ & $21.57 \pm 0.33$ & $19.30 \pm 0.60$ & $19.66 \pm 0.58$ & $20.57 \pm 0.60$ \\
\hline T. procumbens & $6.33 \pm 0.57$ & $6.0 \pm 0.57$ & $7.10 \pm 0.33$ & $6.57 \pm 0.33$ & $6.33 \pm 0.10$ & $7.0 \pm 0.57$ \\
\hline C. gigantean & $6.57 \pm 0.33$ & $7.10 \pm 0.58$ & $6.57 \pm 0.33$ & $7.0 \pm 0.33$ & $6.58 \pm 0.33$ & $6.10 \pm 0.57$ \\
\hline
\end{tabular}


Fig.1 The effect of antibacterial activity of crude plant extracts on UTI bacterial isolates

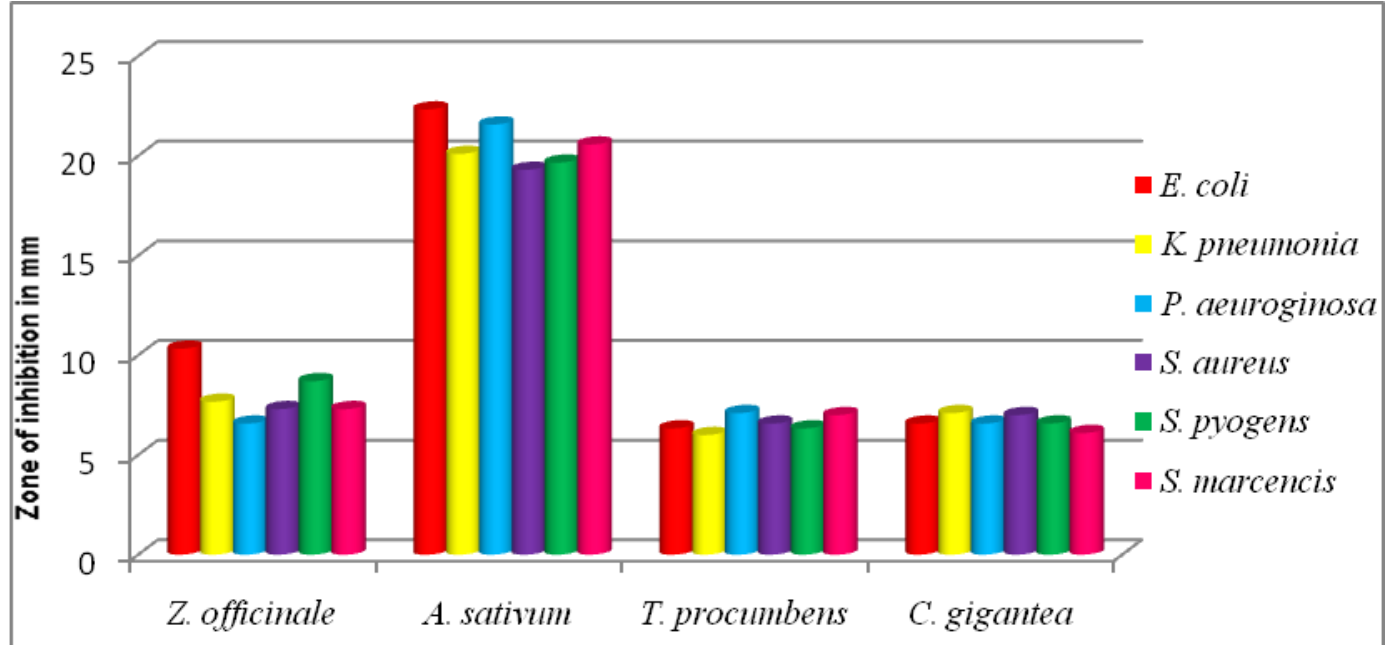

Results obtained for antibacterial studies reveal following findings crude extracts of plants exhibited antibacterial activity towards all six isolates of UTI pathogens. There was significant variation in the antibacterial activities of different plant extracts. Crude extract of Allium sativum formed the maximum zone of inhibition against all bacterial isolates $(22.33 \mathrm{~mm})$. Zingiber officinale was made a moderate inhibition zone $(10.33 \mathrm{~mm})$ Tridax procumbens and latex of Calotropis gigantea were formed only a minimum zone of inhibition against all bacterial isolates up to $7.10 \mathrm{~mm}$ (Table 5). These findings were correlated with work of Daniyan and Muhammad, (2008) and Sathya et al. (2013).

Based on the results obtained from susceptibility test that all the bacteria isolates from UTI pathogen Staphylococcus aureus resistant to all antibiotic except ciproflaxacin. Klebsiella pnemoniae showed the highest degree of resistance to streptomycin and amoxicillin.

All bacterial isolates were sensitive to ciproflaxacin, S. marcensis sensitive to all antibiotics, Streptococcus pyogens was moderatively sensitive to streptomycin, tetracyclin and erythromycin. Our study also agreed with the findings of similar studies done on UTI pathogens by Panlilio et al., 1992 and Hazarika et al., 1990.

\section{References}

Akenga, T., Orech, F.O., Ochora, J., Friis, H and Aagaard, H. 2005. Potential Toxicity of some Traditional Leafy Vegetables consumed in Nyang'oma Division, Western Kenya African $J$. Food and Nutri. Sci., 5: 1-9.

Clinical Laboratory Standards Institute (CLSI). 2015. Method for antimicrobial dilution and disk susceptibility testing of infrequently isolated or fastidious bacteria. Approved guidelines. $3^{\text {rd }}$ edn, CLSI document - M45 - A2, 29(96-97).

Daniyan and Muhammad, H.B. 2008. Evaluation of the antimicrobial activities and phytochemical properties of extracts of Tamaridus indica against some diseases causing bacteria, African J. Biotechnol., 7(14): pp. 2451-2453.

Elder, J.S. Urinary Tract Infection. Nelson Textbook of paediatrics. $17^{\text {th }}$ Edn. 
Philadelphia: WB Saunders Company, 2004. 1621-1625.

Tabassum, H., Mir Naiman Ali, Noura AlJameil and Farah Aziz Khan. 2013. Evaluation of antibacterial potential of selected plant extracts on bacterial pathogens isolated from Urinary Tract Infections. Int. J. Curr. Microbiol. App. Sci., 2(10): 353-368.

Hazarika, R.A., P.N. Mahanta. 1990. Invitro drug sensitivity of bacteria isolated from dermatitis of cattle. Indian J. Vet. Med., 10: 80-81.

Iroha, I.R., M.U. Adikwu, C.U. Esimone, I. Aibinu and Anadi, E.S. 2009. Extended spectrum Beta-Lactamase (ESBL) in E. coli isolated from a tertiary hospital in Enugu State, Nigeria. Pak. J. Med. Sci., 25: 279282.

Kebira, A.N., Ochola, P., Khamadi, S.A. 2009. Isolation and antimicrobial susceptibility testing of Escherichia coli causing urinary tract infections. $J$. Appl. Biosci., 1320-1325.

Krieg, N.R. and Holt, J.C. (eds., 1984). Bergey's Manual of Systematic Bacteriology, $1^{\text {st }}$ ed., vol. 1, Williams and Wilkins, Baltimore.

Kunin, C., 1997. Urinary tract infections. $5^{\text {th }}$ ed., Baltimore: Williams and Wilkins: 301-304.

Mac Faddin, F.J. 2000. Biochemical tests for identification of medical bacteria. $3^{\text {rd }}$ ed., Philadelphia: Lippincott Williams and Wikins.

Mayo Clinic Staff. 2012. Mayo foundation for medical education and research "Diseases and Conditions - Urinary Tract Infection (UTI)". Mayo Clinic.

Panlilio, A.L., D.H. Culver, R.P. Gaynes, S. Banerjee, T.S., Henderson, J.S. Tolver and W.J. Martance. 1992. Methicillin-resistant Staphylococcus aureus in US hospitals. 1975-1991. Infect. Contr. Hosp. Epid., 13:582586.

Sathya Jagadeesan, Vidhya Natarajan and Rajitha. E. Vijayan. 2013. Antibacterial activity of selective plant extracts against urinary tract infection causing organisms. J. Microbiol. Biotech. Res., 3(3): 1-5.

Schaffer, A.J., N. Raja, Q. Cao, B.E. Anderson, D.L. Pruden, J. Sensibar and Duncan, dJL. 2001. Host pathogenesis in urinary tract infection. Int. J. Antimicrob. Agents, 17: 245251.

Shokeen P, Bala M, Tandon V. 2009. Evaluation of the activity of 16 medicinal plants against Neisseria gonorrhoeae. Int. J. Antimicrob. Agents, 33(1):86-91.

Zelikovic, I., R.D. Adelman and P.A Nan Carrow, West. 1992. Antibacterial activity of selective plant extracts against urinary tract infection causing organisms, J. Med., 157: 554-551.

\section{How to cite this article:}

Senthil Kumar, R., and Parameshwari, V. 2017. Studies on Efficiency of Medicinal Plants against Bacteria Isolated from Urinary Tract Infection. Int.J.Curr.Microbiol.App.Sci. 6(1): 258263. doi: http://dx.doi.org/10.20546/ijcmas.2017.601.031 